\title{
Construction of high-rise building with underground parking in Moscow
}

\author{
Vyacheslav Ilyichev $^{1,2}$, Nadezhda Nikiforova ${ }^{2,3^{*}}$ and Artem Konnov ${ }^{2,3}$ \\ ${ }^{1}$ Russian Academy of Architecture and Construction Sciences, 107031, 24/1, Bol'shaya Dmitrovka, \\ Moscow, Russia \\ ${ }^{2}$ Research Institute of Building Physics, 127238, 21, Lokomotivnyj proezd, Moscow, Russia \\ ${ }^{3}$ Moscow State University of Civil Engineering, Yaroslavskoe shosse, 26, Moscow, 129337, Russia
}

\begin{abstract}
Paper presents results of scientific support to construction of unique residential building $108 \mathrm{~m}$ high with one storey underground part under high-rise section and 3-storey underground parking connected by underground passage. On-site soils included anthropogenic soil, clayey soils soft-stiff, saturated sands of varied grain coarseness. Design of retaining structure and support system for high-rise part excavation was developed. It suggested installation of steel pipes and struts. Construction of adjacent 3storey underground parking by "Moscow method" is described in the paper. This method involves implementation of retaining wall consisted of prefabricated panels, truss structures (used as struts) and reinforced concrete slabs. Also design and construction technology is provided for foundations consisted of bored piles 800 мм in diameter joined by slab with base widening diameter of $1500 \mathrm{~mm}$. Experiment results of static and dynamic load testing (ELDY method) are considered. Geotechnical monitoring data of adjacent building and utility systems settlement caused by construction of presented high-rise building were compared to numerical modelling results, predicted and permissible values.
\end{abstract}

\section{Introduction}

In 2014, on Leninsky Avenue in Moscow, BESTCON company (construction project by Metropolis LLC and ZEST LTD.) began the construction of a high-rise building with an attached three-storey parking. The building has class KC-3 according to [1] and has unique status because its height is $108 \mathrm{~m}$. In compliance with the requirements of Russian standards [2] design and construction of the project was conducted with scientific support under the guidance of V. A. Ilyichev (academician of Russian Academy of Architecture and Construction Sciences (RAASN)) and carried out by the Research Institute of Building Physics of the RAASN (NIISF RAASN).

In the course of work on scientific support the following issues were resolved: design approval of the excavation retaining structures for one-storey underground level and threestorey underground car park, review of pile testing protocols, monitoring of concrete strength in above-ground and underground structures, the settlement prediction of the high-rise

\footnotetext{
*Corresponding author: n.s.nikiforova@mail.ru
} 
building, the adjacent school building and utility systems, testing of window units and piers on the upper floors of the building subjected to wind load, prediction of the impact on surrounding buildings and the necessity of mitigation measures, analysis of the geotechnical monitoring results and etc.

\section{Project Details}

\subsection{Geology of the site}

Geological engineering cross-section of the construction site from the top to down is represented by the following soils (in brackets are the thickness of the layers): anthropogenic soils, predominantly lean clays $(0.4$ to $9.1 \mathrm{~m})$, quaternary deposits - firm-stiff clays (0.7-3.6 $\mathrm{m})$, lean clays soft-to-stiff $(4-20 \mathrm{~m})$, firm-stiff clays $(0.5-2.2 \mathrm{~m})$, very soft-stiff silty clays $(0.5$ to $4.9 \mathrm{~m}$ ) covering early cretaceous sands from silt to medium (up to $59.2 \mathrm{~m}$ ). Physical properties and strength of soil are given in table 1.

In the soil mass there are perched water table at a depth of 1.0-5.1 m, and two water levels: at a depth of 4.5-6.7 m, with a hydraulic head of 0.6-2.6 $\mathrm{m}$ and above jurassic deposits at a depth of $22.8-24.0 \mathrm{~m}$. The level of surface is $196,300 \mathrm{~m} \mathrm{[3]}$.

Table 1. Physical properties and soil strength.

\begin{tabular}{|c|c|c|c|c|}
\hline Type of soil & Thickness, $\mathbf{m}$ & $\boldsymbol{E , ~} \boldsymbol{M P a}$ & $\boldsymbol{C}_{\boldsymbol{n}, \boldsymbol{k P a}}$ & $\boldsymbol{\varphi}_{\boldsymbol{n}}{ }^{\circ}$ \\
\hline $\begin{array}{c}\text { anthropogenic soil: lean } \\
\text { clay } \\
\text { firm-stiff }\end{array}$ & $0.4-9.1$ & - & - & - \\
\hline $\begin{array}{c}\text { clay } \\
\text { firm-stiff }\end{array}$ & $0.7-3.6$ & 15 & 0.28 & 18 \\
\hline $\begin{array}{c}\text { lean clay } \\
\text { soft-firm }\end{array}$ & $1.3-8.1$ & 17 & 0.21 & 17 \\
\hline $\begin{array}{c}\text { lean clay } \\
\text { firm-stiff }\end{array}$ & $1.0-5.2$ & 11 & 0.27 & 18 \\
\hline $\begin{array}{c}\text { lean clay } \\
\text { stiff }\end{array}$ & $1.0-3.7$ & 22 & 0.43 & 19 \\
\hline $\begin{array}{c}\text { clay } \\
\text { firm-stiff }\end{array}$ & $0.5-2.2$ & 17 & 0.49 & 18 \\
\hline $\begin{array}{c}\text { silty clay } \\
\text { very soft-stiff }\end{array}$ & $0.5-4.9$ & 19 & 0.21 & 23 \\
\hline $\begin{array}{c}\text { sand } \\
\text { fine, from medium } \\
\text { dense to dense }\end{array}$ & up to 59.2 m & $40-50$ & $0.18-0.08$ & $35-36$ \\
\hline
\end{tabular}

\subsection{Structures of high-rise building and underground parking}

Design of above-ground and underground building structures was carried out in accordance with the requirements of Russian standards for high-rise [4,5] and underground construction $[2,6,7]$. High-rise construction is a research subject for Russian ([8], etc.) and foreign authors ([9], etc.).

Experience of underground space development of Russian cities, reflecting the problems of mitigation measures application for surrounding buildings and structures, evaluation of technological settlement, is described in the papers [10-17]. 


\subsubsection{Structural design of high-rise building}

Residential 33-storey building with built-in 1-storey underground level (Fig.1) has an attached underground 3-storey car parking with single storey aboveground pavilion, which is the entry to the underground parking. One-storey underground level under the high- rise part of the building connected by an underground passage in the first underground floor at level -5,200 with a 3-storey underground parking. Dimensions of high-rise part are $71.5 \times 29.6$ $\mathrm{m}$, attached underground part $-103.3 \times 35.0 \mathrm{~m}$. The retaining structure of a one-storey underground level excavation was designed from metal pipes 426x10 mm $13 \mathrm{~m}$ long with metal wale beam and wooden lagging, with corner struts and raker struts of pipes with a diameter 530x10 and 630x10 mm, respectively (Fig.2). Prime excavation was pre-arranged with depth of $4.0 \mathrm{~m}$. The load bearing structures of the building are reinforced concrete walls and columns.

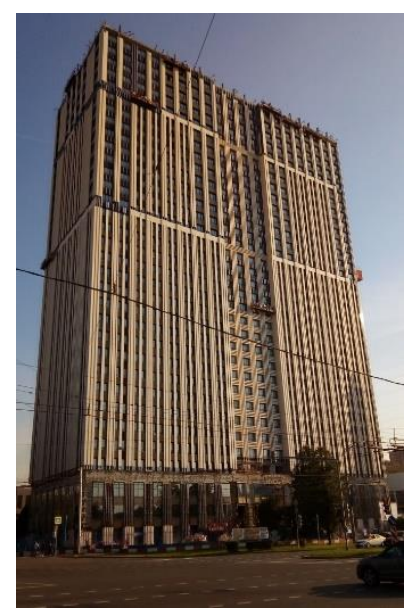

Fig. 1. Construction of the high-rise building at Leninsky Avenue street in Moscow with attached underground parking.

Foundations under high-rise part of the building consist of bored piles joined by slab 2.0 $\mathrm{m}$ of thickness. From the bottom of the excavation, having a depth of $7.45 \mathrm{~m}$, length of the piles is $23.5 \mathrm{~m}$ with a base widening of $1.5 \mathrm{~m}$ and a height of $1.5 \mathrm{~m}$. The relative level of the low pile end is $-29,450 \mathrm{~m}$. Bored piles have a diameter of $800 \mathrm{~mm}$, the spacing is 3.5 and $2.5 \mathrm{~m}$. Under the end of piles there are the cretaceous fine sands. Piles are drilled in this stratum to not less than $1 \mathrm{~m}$. Absolute level of the pile end is $166.85 \mathrm{~m}$. The piles are drilled from a ground surface, although they are casted up to the bottom of the pit. Above the pit shafts are filled to the surface with gravel.

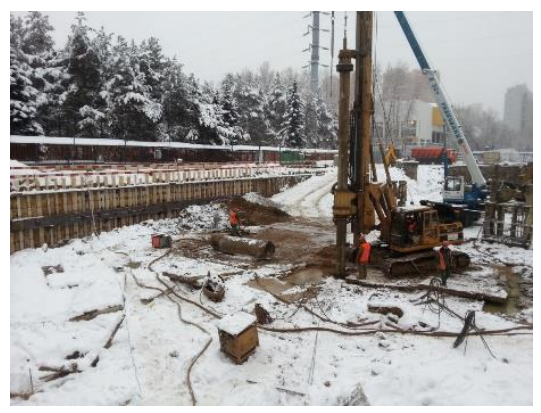

Fig. 2. The retaining structure for the excavation and pile drilling. 
The base widening of the piles was carried out by mechanical means. Fig. 3 shows the used widening tool.

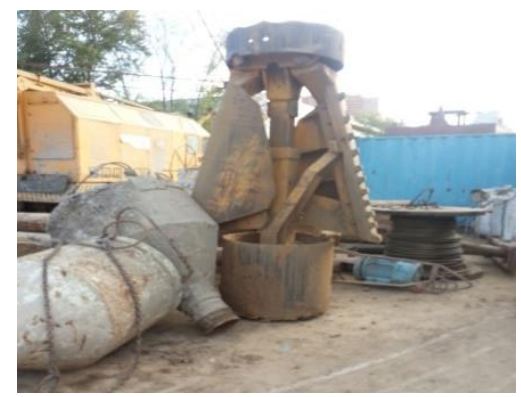

Fig. 3. The widening tool.

\subsubsection{Structural design of 3-storey underground parking}

The depth of the pit was $12.20 \mathrm{~m}$ (absolute level of the bottom was $182.595 \mathrm{~m}$ ). Diaphragm wall, thickness of $600 \mathrm{~mm}$ - precast-monolithic, load bearing, buried into confining bed, buried depth below the bottom of the pit is $5.0 \mathrm{~m}$ (abs. level $177.60 \mathrm{~m}$ ). Permeability without block wall secured through the use of prefabricated elements of high water-resistance (W12) concrete, which are arranged on the internal side and provide no filtering of water through the section of the diaphragm wall (Fig. 4).

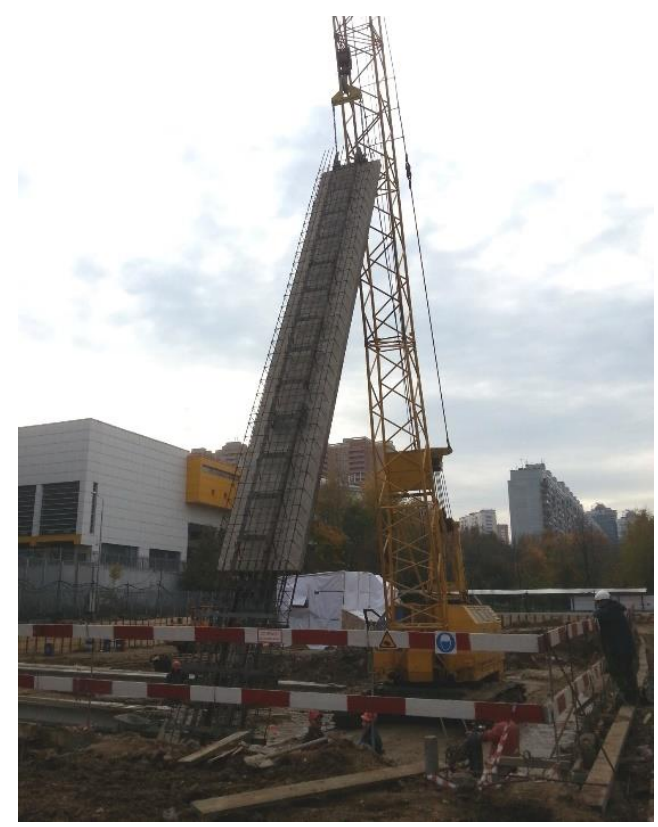

Fig. 4. Precasted panel for diaphragm wall of 3-storey parking.

The construction of underground parking is realized by "Moscow method", which is an improvement of the "top-down" method and includes retaining technology for excavations executed by two major slabs, "truss" bars between them and the two cable anchorages at the corners of the pit (Fig.5). This excavation retaining method is protected by Russian patent No. 2220258 [18] etc. 


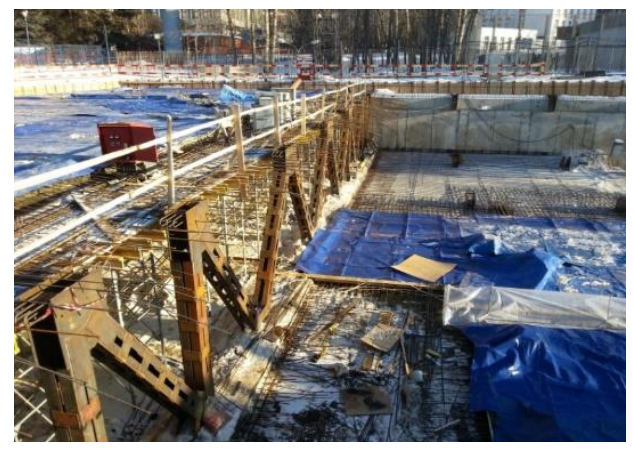

Fig. 5. Construction of 3-storey underground parking. Slab supported by truss structures.

\section{Results of scientific support}

\subsection{Evaluating of piles bearing capacity on the site}

The bearing capacity of the bored piles was determined on-site by ELGADTOP company. Two methods were used: static load (two piles) according to [19] and dynamic load by the ELDY method (two piles) according to the test programme, developed by ELGADTOP [20] and proved by NIISF RAASN. While testing pile No. 66 (Fig.6) with static load the supplement piles No. 36,38,96,98 were used as an anchors. The load was applied in five steps. The settlement of pile reached $18.9 \mathrm{~mm}$. Bearing capacity of the pile estimated $\mathrm{F}_{\mathrm{d}}=$ 885 ts.

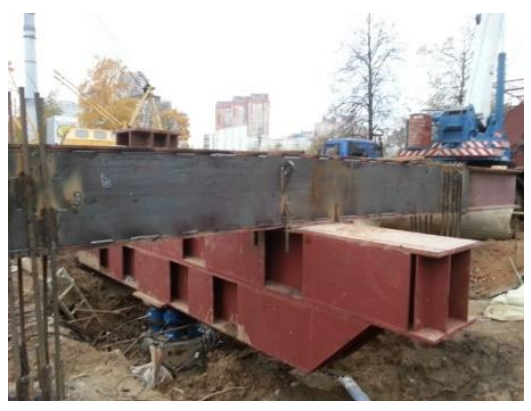

Fig. 6. Pile No. 66 static test.

The image of the pile after testing by ELDY method (Fig.7) indicates that the pile is not damaged.

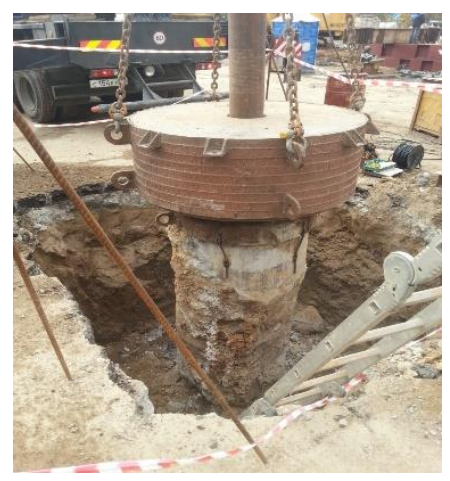

Fig. 7. Pile No. 237 after ELDY test. 
Fig. 8 depicts a computer monitor that records the process and parameters of the test.

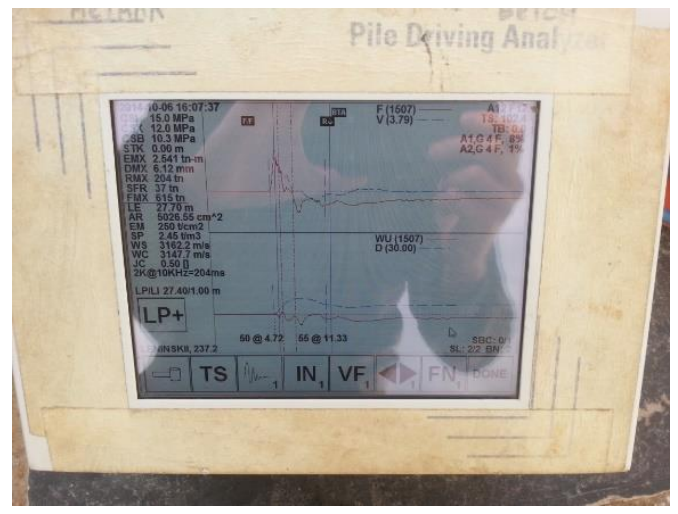

Fig. 8. Computer monitor recording the ELDY test process of pile No. 237.

The design length of pile No. $145-29.48$ m; pile No. $237-29.62$ m. Class of concrete is B40 , 21 days passed after casting. Achieved settlements: pile No. $145-18 \mathrm{~mm}$, pile No. $237-16 \mathrm{~mm}$. Bearing capacity of the pile according to the test $\left(\mathrm{F}_{\mathrm{d}}\right)$ : No. $237-1113,7 \mathrm{tf}$, pile No. 145 - 1082, 4 tf.

It's necessary to admit that the piles were casted and tested from the surface but would work from the depth of $\sim 8 \mathrm{~m}$ taking into account underground part of the building. To determine the bearing capacity of piles $F_{d}$ it's required to subtract the skin friction carrying capacity to a depth of $8.0 \mathrm{~m}$ from the surface, which is $\sim 33,6 \mathrm{tf}$ for the pile No. 237, and 38,5 tf for the pile No. 145 and the pile No. 66 according to the test data collected by ELGADTOP Co. Thus, $F_{d}$ of piles No. 237, No. 145, No. 66 after completion of underground part would be 1080,1044 and $847 \mathrm{tf}$, respectively.

In accordance with clause 7.1.11 [6] the estimated load (N) transmitted to the pile is $739,3 \mathrm{tf}$ (No. 237), 714,6 tf (No. 145) and 676,4 tf (No. 66). The least of three values was chosen for the project $-\mathrm{N} \leq 676 \mathrm{tf}$.

\subsection{Geotechnical forecast and monitoring results}

The school building and utility systems were in the zone of the construction impact. Geotechnical forecast of high-rise building settlements and settlements of the surrounding buildings and structures was provided by PODZEMPROEKT Co. using the software package Midas GTS NX in three dimensional model [3]. An improved model of Mohr-Coulomb was used for these calculations.

Geotechnical monitoring included control of foundation slab displacements under the high-rise part of the building (45 cycles of measurements), monitoring of diaphragm wall around attached underground parking, 3-storey school building, fencing of the Embassy of Germany territory, electric pole and existing underground utilities in the zone of construction impact. Settlements of the high-rise building and the surrounding building and structures were measured at 124 geodetic marks in accordance with [21].

Foundation slab settlements under the stylobate part of the building reached $-7.5 \ldots-15,7$ $\mathrm{mm}$, and under high-rise part of the building $-11,4 \mathrm{~mm} . .-22,3 \mathrm{~mm}$ and did not exceed calculated values of settlement, equal to $65 \mathrm{~mm}$ (Fig. 9) [22, 23]. 


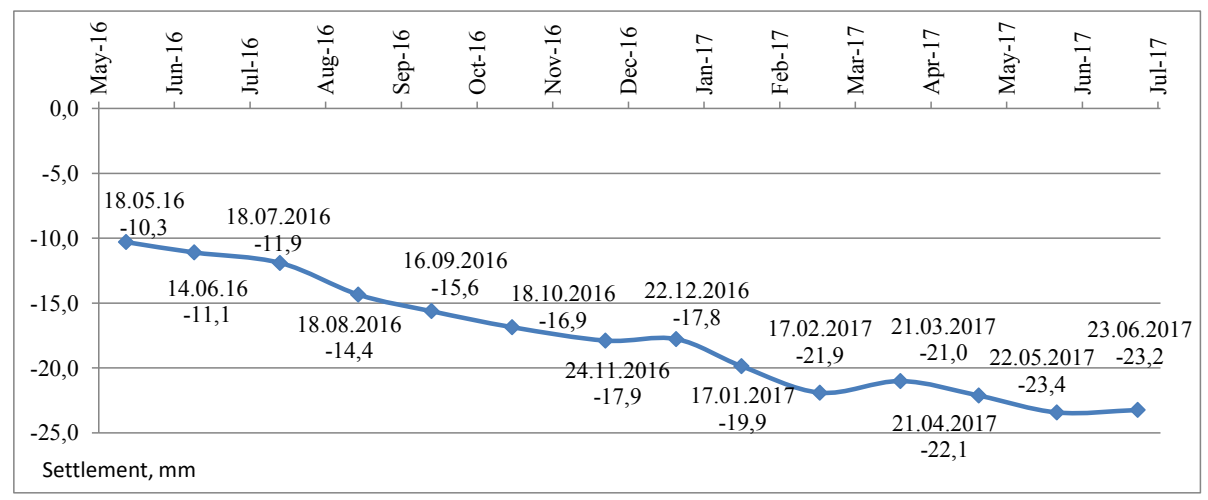

Fig. 9. Maximum settlement of foundation slabs under high-rise and stylobate part of the building.

Displacements of buildings and utilities didn't exceed the predicted values. Mitigation measures for the surrounding buildings and structures weren't required.

Horizontal displacements of the diaphragm wall were measured by engineer's microlevel NE-3e (developed by the Institute of Physics of the Earth (IPE) RAS) at 60 microlevel marks on $-1,-2$ and -3 storeys of the underground parking ( 20 marks on each floor). 37 measurement cycles were made (Fig.10).

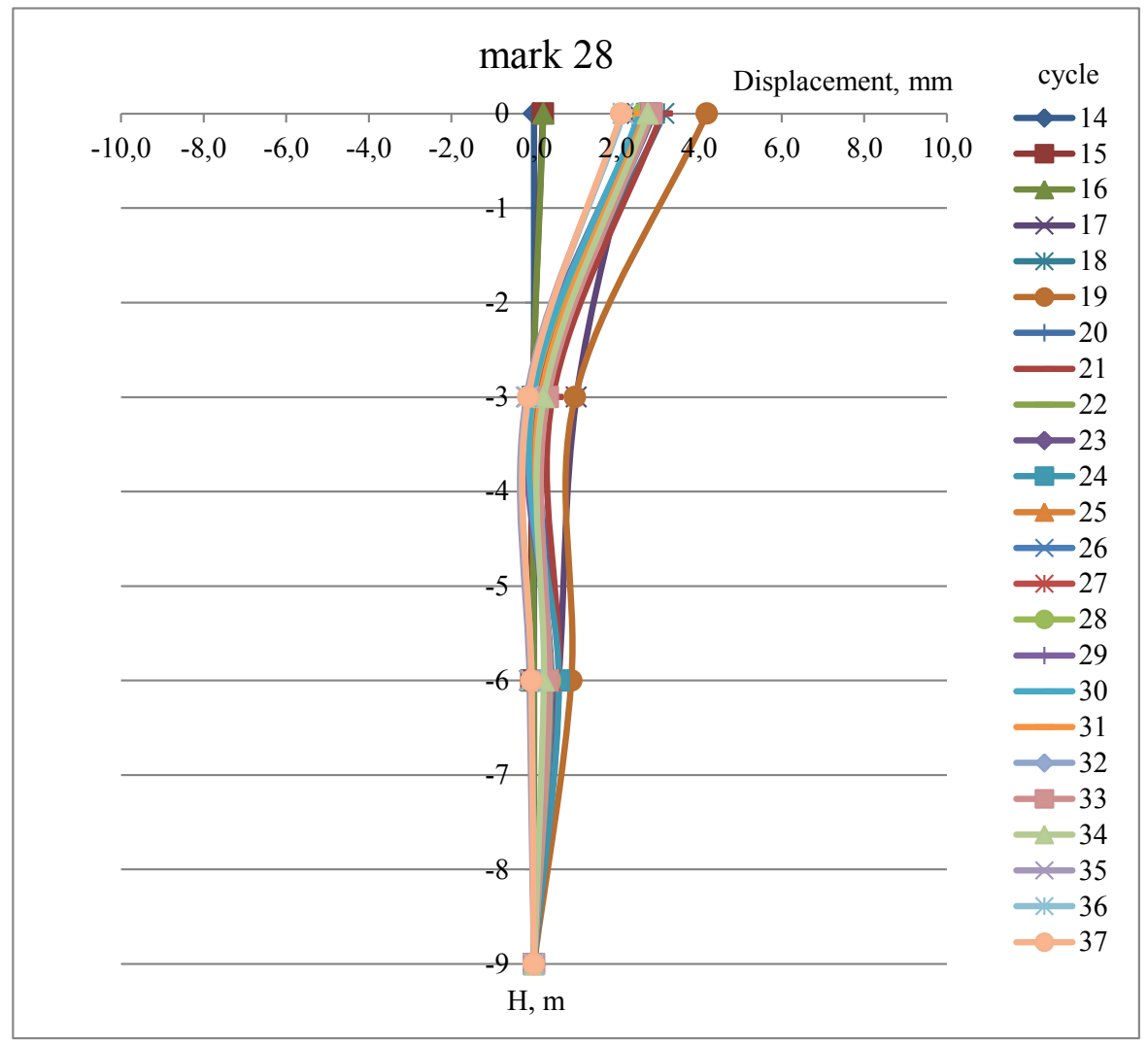

Fig. 10. Schedule change of a horizontal wall position during the construction of parking at crosssection of the observation mark No. 28. 


\subsection{Additional works, executed within scientific support for the design and construction of the high-rise building.}

On the basis of the verification calculations done by PODZEMPROEKT Co. the length of the retaining metal piles was reduced by $1 . . .2 \mathrm{~m}$ on three sides of the pit. Also a design of the support system was changed. Raker struts based at foundation slab were changed to the longitudinal strut resting on a midway support which saved metal and accelerated the works on-site.

During concrete strength control (class B55) in the structures of high-rise building problem pylons have been revealed at level - 0,250 . A concrete in these pylons at the time of testing has strength no more than $90 \%$ of the design value. For this reason verification calculations have been done establishing that the margin of safety in them ranged from 9 to $34 \%$.

In connection with a partial change of the design solutions verification calculations was performed concerning reinforcement of interwindow piers on the influence of the wind load specified in the recommendations given by CNIISK V.A. Kucherenko. These calculations were followed by on-site tests of interwindow piers on wind load, showed the adequacy of reinforcement.

Also tests of window units with valves were conducted to determine the resistance to heat transfer, air and water permeability and also soundproofing. Received results confirmed the usability of chosen window units.

\section{Conclusions}

Scientific support was able to solve a number of issues during the design and construction of high-rise building, for example, potential necessity of mitigation measures for utilities, need for a reliable forecast of high-rise building settlement, confirmation of the "Moscow method" effectiveness for retaining and strutting of underground car park structures, etc.

\section{Acknowledgments}

The authors would like to thank BESTCON Co., ZHILKAPSTROY Co., PODZEMPROEKT Co. for given project documentation and cooperative work at the site.

\section{References}

1. Russian Standard GOST 27751-2014. Reliability for constructions and foundations. General principles.

2. Russian Standard SP 22.13330.2016 Soil bases of buildings and structures.

3. The calculation of the impact on existing utilities and the school building during the construction of a multifunctional residential complex at the address: Moscow, Leninsky prospect, 97-99, as well as development of recommendations for mitigation measures for existing utilities and school building, scientific and technical report PODZEMPROEKT Co., (2014)

4. Russian Standard SP 267.1325800.2016 High rise buildings and complexes. Design rules.

5. Russian Standard MGSN 4.19-05.Multifunctional high-rise buldings and complexes, vol. 1. Moscow standard document.

6. Russian Standard SP 24.13330.2011 Pile foundations.

7. Russian Standard SP 45.13330.2017 Earthworks, Grounds and Footings. 
8. O.A. Shulyatev, Osnovaniya i fundamenty vysotnyh zdanij (ACB, Moscow, 2016)

9. H.G. Poulos, Razvitie gorodov i geotekhnicheskoe stroitel'stvo, 1, 1 (2011)

10. V.A. Ilyichev, R.A. Mangushev, N.S. Nikiforova, Osnovaniya, fundamenty i mekhanika gruntov, 2, 17 (2012)

11. Geotechnical Engineer's Handbook. Footings, foundations, underground structures. 2nd edition. (edited by V.A. Ilyichev, R.A. Mangushev) (ACB, Moscow,2016)

12. V.A. Ilyichev, N.S. Nikiforova, A.V. Konnov, Proc. of 19th ICSMGE, 1789 (Seul, Korea, 2017)

13. V.A. Ilyichev, R.A. Mangushev, N.S. Nikiforova, A.V. Konnov, BST Byulleten' stroitel'noj tekhniki, 6, 68 (2017)

14. R.A. Mangushev, N.S. Nikiforova, Tekhnologicheskie osadki v zone vliyaniya podzemnogo stroitel'stva (ACB, Moscow, 2017)

15. N.S. Nikiforova, Obespechenie sohrannosti zdanij v zone vliyaniya podzemnogo stroitel'stva (MGSU, Moscow, 2016)

16. N.S. Nikiforova, The Proc. of the First U.S.A.- Russia Geotechnical Engineering Workshop, 72 (Oakland, California, 2012)

17. O.A. Shulyatev, O.A. Mozgacheva, V.S. Pospekhov, Osvoenie podzemnogo prostranstva gorodov (ACB, Moscow, 2017)

18. C.O. Zege, I.A. Zege, N.C. Zege, Sposob vozvedeniya mnogoehtazhnogo podzemnogo sooruzheniya. Russian Federation patent №2220258 (2003)

19. GOST 5686-2012 Soils. Field test methods by piles. Russian standard document.

20. Programme of field pile test using impact load (ELDY method) and static load. ELGADTOP Co. (2014)

21. Russian Standard GOST 24846-2012 Soils. Methods of measuring the strains of structure and building bases.

22. V.A. Ilyichev, N.S. Nikiforova, A.V. Konnov, V.R. Irtuganova, ZHilishchnoe stroitel'stvo, 6, 29 (2016)

23. Report for the scientific and technical work. "Geotechnical monitoring for the construction project "Multifunctional residential complex with underground parking at the address: Moscow, Leninsky prospect, 97-99". Step 11. Geotechnical monitoring at the construction site (April-June 2017)”. NIISF RAASN Research institute. (2017) 